(C) 2012

Довжик О. О., кандидат економічних наук

Сумський національний аграрний університет

\title{
РОЛЬ УПРАВЛІНСЬКОГО ОБЛІКУ ТА ПРОБЛЕМИ ЙОГО ВПРОВАДЖЕННЯ НА ПІДПРИЕМСТВАХ
}

\section{Рецензент - доктор економічних наук Л. І. Михайлова}

\begin{abstract}
У статті проаналізовано роль управлінського обліку в системі керування підприсмством. Встановлено, щуо управлінський облік є ефективним інструментом управління, тому що створює конкурентні переваги в ринковому середовищі. Виділено основні принщипи побудови системи управлінського обліку на підприємстві сучасного типу, обгрунтовано ї̈ важливість для забезпечення ефективного функціонування. Також проаналізовано основні проблеми, щчо заважають впровадженню управлінського обліку та намічено заходи для успішного здійснення иьього процесу на підприсмствах України.
\end{abstract}

Ключові слова: управлінський облік, система управлінського обліку, витрати, метод обліку витрат, калькулювання собівартості.

Постановка проблеми. Сучасні методи керівництва господарством та виробництвом вимагають більш детальної організації бухгалтерського обліку на підприємстві. 3 кожним днем збільшується кількість керівників українських підприємств, які перестають сумніватися в необхідності вести облік, відмінний від бухгалтерського, який практично повністю зосереджений на задоволенні потреб зовнішніх споживачів інформації. Управлінський же облік призначений для надання достовірної і повної інформації, яка необхідна для прийняття правильних та ефективних управлінських рішень самого підприємства. Але в практичній діяльності керівники українських компаній досі не мають чіткого розуміння цього виду обліку, що, мабуть, є головною проблемою процесу постановки системи управлінського обліку. Однією з найважливіших проблем функціонування підприємств України в ринкових умовах $\epsilon$ налагодження системного контролю за витратами як основного засобу досягнення належної ефективності діяльності. Вирішенню цієї проблеми має сприяти управлінський облік, або система управління витратами.

Розробка і введення управлінського обліку на підприємствах - це частина загального процесу реформування системи бухгалтерського обліку в Україні. На сьогодення дана тематика є актуальною, адже будь-яке підприємство бажає знати, яка продукція користується найбільшим попитом, які витрати необхідні на їі випуск, який дохід принесе їі реалізація в майбутньому.

Аналіз основних досліджень та публікацій, у яких започатковано розв'язання проблеми. Сьогодні в економічних дослідженнях використовуються різні розробки, присвячені питанням управлінського обліку як інструменту управління підприємствами. Дослідження питань теорії i практики організації системи управлінського обліку в Україні проводять такі науковці, як I. Бєлоусова [1, с. 34], Л. Гнилицька [2, с. 24], Л. В. Нападовська [5, с. 50], М. С. Пушкар [6, c. 116], Н. Г. Чумаченко [8, с. 12] та інші. Проте поряд із важливими науковими результатами щодо методики і організації управлінського обліку все ще залишаються невирішеними проблеми в основному його практичного використання.

Мета і завдання досліджень. Метою статті $\epsilon$ обгрунтування необхідності управлінського обліку та основних принципів побудови його системи на підприємстві з метою забезпечення ефективного функціонування.

Завданнями досліджень було: розглянути та визначити важливість управлінського обліку; виявити проблеми його впровадження в сучасних умовах господарювання та намітити шляхи упровадження системи управлінського обліку.

Матеріали і методи досліджень. Для написання статті були використані результати досліджень провідних вчених-економістів. Досягненню цілі сприяли загальнонаукові методи: методи теоретичних досліджень (аналіз і синтез), абстрактно-логічний (теоретичні узагальнення та формування висновків), історико-економічний та класифікаційно-аналітичний.

Результати досліджень. В сучасний період на більшості підприємств України управлінський облік ще не сформувався як цілісна система збору, аналізу, інтерпретації і представлення корисної інформації менеджерам підприємства 3 ціллю прийняття на її основі оперативних, тактичних та стратегічних рішень. Відсутня єдина методична база формулювання управлінського об- 


\section{EKOHOMIKA}

ліку як системи. Приведене поняття в законі «Про бухгалтерський облік і фінансову звітність в Україні», «управлінський (внутрішньогосподарський) облік - це система обробки та підготовки інформації про діяльність підприємства для внутрішніх користувачів в процесі управління підприємством», являється вузько орієнтуючим і не відображує справжню його сутність [4].

Управлінський облік повинен забезпечити мінімізацію витрат на виробництво продукції й одержання максимального прибутку. Відповідно до інтересів користувачів управлінський облік має відповідати таким цілям: децентралізація контролю, в розрізі центрів відповідальності, за обліком витрат і формуванням собівартості продукції; впорядкування інформації в управлінській звітності, необхідної для прийняття управлінських рішень і розробки стратегічних дій підприємства. Пушкар М. С. підкреслює, що особливістю управлінського обліку $є$ те, що на місце чисто процедурних обліково-економічних завдань висувається нове завдання - забезпечення потреб користувачів у такій інформації, яка носить адресний характер, тому зрозуміло, що для різних груп користувачів треба забезпечити різну інформацію [6, с. 116].

Головною метою управлінського обліку, наголошують Л. К. Сук і П. Л. Сук, є оперативне складання і подання внутрішньої звітності, необхідної для прийняття управлінських рішень 3 метою контролю використання ресурсів, виконання договорів, руху коштів та інших чинників, які впливають на одержання прибутку і досягнення успіхів на ринку [3, с. 573].

Потрібно зазначити, що метою управлінського обліку є не тільки відображення економічних процесів, а й управління ними. Нападовська Л. В. зазначає, що метою управлінського обліку є допомога внутрішнім користувачам приймати більш обгрунтовані рішення, забезпечення менеджерів інформацією, яка надає можливості примножити капітал їі власникам, а працівникам підприємства - збільшити цінність їх матеріального та духовного добробуту,підвищення ефективності управління, а отже - ефективності планування, нормування, контролю та прийняття управлінських рішень [5, с. 50].

Перехід до ринкових відносин вимагає розробки i впровадження нових форм організації діяльності підприємств, перегляду існуючої системи бухгалтерського обліку і визначення іiі місця та значення в системі управління. Це зумовлює необхідність вивчення загального історичного розвитку світової бухгалтерії 3 метою досягнення найефективніших результатів реформування. В сучасний період одне з головних місць у практиці управління країн з розвитою ринковою економікою займає концепція управлінського обліку.

Тому виникає питання у більшості підприємців: яким же повинен бути сучасний управлінський облік - облік «за всіма його правилами», і 3 чого треба починати його побудову?

Сутність управлінського обліку, його призначення можна коротко передати визначенням: «виробництво» інформації для здійснення ефективного управління.

Управлінський облік - це система планування i координації. Це невід'ємна частина менеджменту, в тому числі фінансового. Ця розгалужена i багаторівнева система включає в себе стратегію, механізм та інструментарій. Для застосування управлінського обліку не має значення розміри організації. Ця система пристосовується як до малого підприємства, так і до великої корпорації. Тільки набір інструментів різний.

Таким чином, управлінський облік можна охарактеризувати як інтегруючу систему підготовки ключової інформації і забезпечення нею різних рівнів управління 3 ціллю ефективного планування, контролю і покращання якості приймаючих рішень. В системі управлінського обліку, крім того, здійснюється оцінка прийнятих рішень на різних рівнях управління з точки зору відповідності загальної стратегії підприємства.

Створення цінності в системі управлінського обліку - це і $є$ «виробництво» ключової інформації, яка забезпечує конкурентні переваги будьякому підприємству. В сучасному розумінні в терміні «управлінський облік» все більше наголос робиться на слові «управлінський», оскільки організація і методика цього виду обліку направлена на рішення саме управлінських задач. Виникнення та існування управлінського обліку обумовлені конкретною ціллю - допомогти внутрішнім користувачам приймати більш обгрунтовані рішення.

Традиційні підходи до поняття того, що система обліку повинна включати лише внутрішню інформацію, а діяльність розглядається як одна головна стаття витрат підприємства, на сьогоднішній день $є$ неприпустимими. Система вітчизняного обліку повинна бути орієнтована не лише на виробництво, а й на ринок. Мислення, зорієнтоване на продукцію, повинно змінюватися на мислення, зорієнтоване на вирішення проблем клієнтів.

Управлінський бухгалтерський облік спрямований на формування інформації для прийняття 
управлінських рішень внутрішнім користувачам. Він не регулюється загальноприйнятими принципами та організується підприємством самостійно. Більшість даних управлінського обліку $є$ комерційною таємницею, поскільки вони відображають стратегію і тактику підприємства в умовах конкуренціі. Тому саме менеджери підприємства $є$ користувачами управлінської інформації.

Управлінський облік забезпечує підготовку i аналіз бухгалтерської інформації, щоб допомогти керівництву в управлінні, плануванні й контролі діяльності підприємства, поскільки надає інформацію про формування собівартості, забезпечує даними про відхилення фактичних показників від прогнозних значень в оперативному порядку.

Важливу роль відіграє управлінський облік при вирішенні завдань прогнозного характеру: про рентабельність нових видів продукції; визначення очікуваного доходу від запланованих господарських заходів; оцінки ефективності нових інвестицій; прийняття рішень в умовах використання обмежених ресурсів, а також рішень типу «купувати чи виробляти» тощо. Управлінський облік - це синтез методів і принципів обліку витрат, калькулювання собівартості, а також прогнозування, планування (бюджетування), аналізу і контролю.

Керівників різних рівнів управління в більшій мірі цікавлять не стільки результати їх минулої діяльності, скільки способи досягнення бажаних результатів діяльності власного підприємства в майбутньому. Керівникам уже недостатньо знати, скільки коштує та чи інша продукція - для них важливо, чому вона стільки коштує, а головне, як зробити так, щоб i виробництво було вигідним? У країнах, де бухгалтерський облік прийнято розділяти на фінансовий і управлінський, прогностична функція характерна саме для управлінського обліку. Це стало реальним на основі бюджетування, прогнозування поведінки витрат і доходів, експертних оцінок, розробки альтернативних рішень. Тому в останні роки все більше розповсюдження отримують стратегічні системи управлінського обліку як результат прагнення розширити інформаційну базу для прийняття рішень за рахунок формування прогнозної інформації.

Управлінський облік, будучи продовженням фінансового обліку, має з ним реальний, справжній взаємозв'язок і певні відмінності. Управлінський облік - відображення в зручній формі фінансово-господарської діяльності підприємст- ва в ході виконання плану. Він орієнтований на внутрішніх користувачів інформації, на відміну від бухгалтерського. Проте, не дивлячись на відмінності між фінансовим і управлінським обліком існує подібність (схожість), котра проявляється через елементи методу, об'єкти обліку i єдність вихідної інформації.

Однак ведення фінансового обліку визначається вимогами міжнародних стандартів бухгалтерського обліку та фінансової звітності. Тому дані фінансового обліку відображують результати минулої діяльності підприємства. Досить влучно відмінність між фінансовим і управлінським обліком охарактеризував С. Голов: «... Можна сказати, що бухгалтери-аналітики це Нострадамуси бізнесу, а бухгалтерирахівники - це Нестори-літописці» [3, с. 20].

Усвідомлення потреби та бажання запровадити управлінський облік ще недостатньо для здійснення цього наміру. На шляху впровадження управлінського обліку $є$ певні перешкоди, які полягають у подоланні дискусійних проблем методології обліку та в необхідності організаційних заходів щодо його впровадження.

Слід звернути увагу на опис системи контролю за витратами на обслуговування виробництва та управління. Ці витрати відносять до непрямих i для контролю за ними складають кошториси витрат по підрозділах та підприємству в цілому. Однак планові кошториси витрат складають із розрахунку на плановий обсяг виробництва. Поскільки фактичний обсяг виробництва відхиляється від планового, в компаніях США запроваджена система гнучких кошторисів, де витрати планують варіантно-перевиконання плану виробництва та невиконання плану в межах 5-7\%. При цьому використовується поділ витрат на постійні, змінні та напівзмінні. Собівартість альтернатив розраховують по кожній статті витрат залежно від їх «поведінки» щодо змін обсягів виробництва продукції: статті постійних витрат не змінюються, статті змінних витрат перераховують пропорційно до зміни обсягу виробництва (продаж), статті напівзмінних витрат змінюються частково щодо зміни обсягів.

Варто наголосити, що в зарубіжній практиці значного поширення на підприємствах набуває метод «директ-костинг», який ще називають методом обліку неповної собівартості. На вітчизняних підприємствах даний метод ще не набув значного використання через те, що вступає у протиріччя 3 вимогами податкового та бухгалтерського обліку. В основу цього методу покладено облік витрат за виробами або групами ви- 
робів тільки щодо прямих витрат: основні матеріали, купівельні напівфабрикати та основна заробітна плата працівників. Цей метод дає змогу знизити трудомісткість облікових операцій i оперативно здійснювати розробку проектів управлінських рішень з урахуванням впливу собівартості продукції. Однак при цьому спостерігається ототожнення прямих витрат зі змінними. Так, у статті Л. Гнилицької щодо прийняття управлінських рішень вказується на доцільність використання в обліку системи «директкостинг», тобто системи калькулювання змінних витрат [2, с. 24]. Даний метод базується саме на визначенні змінних виробничих витрат. У цьому випадку основні труднощі полягають у відокремленні постійних витрат.

Термін «змінні витрати» стосується тих витрат, величина яких змінюється пропорційно до зміни обсягу виробництва. Тому прямі витрати значною мірою збігаються зі змінними, але не дорівнюють їм. У деяких випадках автори змішують класифікацію виробничих витрат за способом включення їх до собівартості продукції на прямі та непрямі $з$ класифікацією витрат залежно від впливу зміни обсягу виробництва продукції: змінні та постійні.

Суттєвим гальмом поширення управлінського обліку в країні залишається відсутність чіткого визначення переліку складових цього обліку. Завдяки управлінському обліку бухгалтер за потребою, крім власне обліку та калькулювання собівартості продукції, займається нормативним плануванням, економічним аналізом та підготовкою управлінських рішень [1, с. 34].

На думку Бєлоусової І., бухгалтерський облік доцільно поділити на дві частини: облік виробничих витрат та калькулювання собівартості продукції [1, с. 34].

Досвід підприємств України свідчить, що практичне застосування управлінського обліку ще не набуло належного поширення. Практичний бік застосування управлінського обліку ставить перед керівництвом підприємства конкретні завдання організаційного характеру, а саме: чи доцільне використання цього виду обліку; чи створювати управлінську бухгалтерію; який має бути порядок формування інформації про витрати, обсяг виробництва та систему контролю за цими показниками тощо. Винятковий вплив на вирішення цих проблем мають галузеві організаційні та інші особливості конкретного підприємства, наявність внутрішньої й зовнішньої звітності тощо.

Вирішальне значення при цьому мають віді- гравати розміри підприємства, потреби щодо забезпечення інформацією всіх рівнів управління та методики збору й опрацювання даних.

Однак найбільші складності для успішного впровадження управлінського обліку обумовлені особливостями діяльності окремих ланок народного господарства. При цьому мають бути враховані конкретні методичні підходи, які б дали змогу побудувати облік витрат та систему бюджетування відповідно до технології, узгодити 3 функціями витрат, а також запропонувати такі методи, які б допомогли створити належну систему контролю витрат. Таку схему впровадження управлінського обліку запропонував М. Чумаченко ще у 1999 р., однак ця проблема досі не вирішена. У підручниках та посібниках, що вийшли у світ в Україні та за рубежем, на жаль, висвітлено лише загальні положення і зовсім не приділяється уваги особливостям управління витратами в окремих галузях.

На сучасному етапі бухгалтерський облік, по-перше, не задовольняє потреб користувачів i, по-друге, не відповідає економічним відносинам, які формуються. Крім того, сучасна система бухгалтерського обліку не дає змоги створити надійну інформаційну основу для розвитку ринків капіталу, приватизації, збільшення інвестицій та оцінки ефективності функціонування приватного сектора; для використання ресурсів міжнародних фінансових ринків та розвитку міжнародних економічних відносин.

До того ж ситуація ускладнюється тим, що Україна має свої особливості, зокрема:

по-перше, пов'язано 3 тим, що на відміну від країн Америки та Західної Європи, в яких формування і розвиток економіки і системи бухгалтерського обліку відбувалися природнім шляхом протягом десятків і сотень років, в Україні проходить прискорена економічна реформа, що вимагає відповідної зміни системи бухгалтерського обліку;

по-друге, проблема полягає в тому, що через тривалу відірваність від світових господарських процесів, вона перебуває у найгіршій ситуації, від якої, з огляду на брак часу для здійснення економічних трансформацій та суспільногосподарських реформ, потрібно перейти безпосередньо до оптимальної;

по-третє, система вітчизняного бухгалтерського обліку, яка формувалася протягом кількох десятиліть і повністю відповідала інтересам пануючої планової моделі господарювання та управління, виявилася недієздатною в сучасних умовах переходу до ринку і потребує реформування. 
Управлінський облік є складником процесу управління та надає інформацію, важливу для:

- визначення стратегії та планування майбутніх операцій підприємства;

- контролювання іiї поточної діяльності;

- оптимізації використання ресурсів;

- оцінки ефективності діяльності;

- зниження рівня суб'єктивності в процесі прийняття рішень.

Підприємство може самостійно розробляти систему i форми внутрішньогосподарського управлінського обліку, а також звітності і контролю господарських операцій. Отже, неможливо визначити чіткий порядок організації управлінського обліку на кожне підприємство, однак можна визначити цілу низку факторів, які впливають на його побудову, а також визначити загальні принципи організації обліку для управлінських потреб.

Організація бухгалтерського управлінського обліку на підприємстві складається 3 трьох етапів: методологічного; технічного; організаційного.

На першому етапі обирається модель управлінського обліку в залежності від його мети, визначаються об'єкти та методи обліку витрат, а також елементи бухгалтерського обліку, які можуть служити для формування інформації необхідної для прийняття управлінських рішень. Це план рахунків управлінського обліку, складання калькуляційних статей та інше.

На другому - технічному етапі - обирається склад регістрів аналітичного обліку, форми внутрішньої звітності і визначення напрямку руху інформації в середині підприємства.

Третій етап передбачас розподіл обов'язків між працівниками в системі управлінського обліку.

Необхідно офіційно покласти відповідальність за збирання та аналіз даних на конкретних працівників, розробити посадові інструкції для виконавців. Організаційна структура управлінського обліку на підприємстві залежить від організаційної та виробничої структури. Організаційна структура забезпечує узгодженість окремих видів діяльності підприємства, та зусиль із виконання основних завдань та цілей. Виробнича структура підприємства показує склад та структуру цехів, служб, їх потужність, форми побудови та взаємозв'язку на кожному рівні управління підприємством. Побудова виробничої структури підприємства залежить від типу, масштабу підприємства, складності технологічних процесів. Кожний адміністративний рівень керівників повинен мати чітко сформульовані повноваження щодо прийняття рішення. Ефективний розподіл цих повноважень дасть можливість визначити ефективність роботи окремих виконавців. Ефективність виконання повноважень визначатиметься за певними, встановленими на підприємстві показниками. В багатьох випадках це певні норми. Норми відображаються в бюджетах, кошторисах та доводяться до відповідного керівника. Дотримання запланованих показників підтверджується фактом (цифрою, здебільшого у грошовому виразі) виконання. Якщо «бюджетна норма» була реалістичною, то ми чітко знатимемо, 3 яких причин, які фактори вплинули на відхилення й хто відповідатиме за позитивне чи негативне відхилення.

Ефективне управління підприємством залежить значною мірою від розвиненості системи управлінського обліку та ступеня її комп'ютеризації. Вимогам ринкової економіки найбільшою мірою відповідає форма обліку, орієнтована на широке використання мереж ПЕОМ і створення автоматизованих робочих місць бухгалтера. Працюючи із системою управлінського обліку, бухгалтер повинен використовувати хороші програмні продукти. Йому потрібні знання в області аналізу, планування, контролю, а також інструменти для втілення цих знань у життя. Серед програмних продуктів західних виробників багато програм, призначених для управління. Проте всі вони мають головний недолік: вони включають у себе вже «вшиті» управлінські рішення. Проте розробники використовували емпіричний досвід західних, в основному, американських компаній, та ще й досить віддалений за часом. Навіть американські компанії досить змінилися за останні десять років, а українські й зовсім не схожі на американські. Програмні продукти не адаптуються на російський менталітет, на прийоми і методи ведення господарства в Україні.

Вирішення проблем управлінського обліку необхідно здійснювати і на рівні держави (хоча управлінський облік є виключним питанням керівництва підприємством): допомога у формуванні єдиної методологічної бази управлінського обліку, яка повинна бути тісно пов'язана з процесами вдосконалення корпоративного управління; формування «прошарку» кваліфікованих професіоналів у сфері управлінського обліку.

Що стосується упровадження системи управлінського обліку, то для успішного здійснення цього процесу необхідні три невід'ємні складові:

1) спеціальні ресурси для реалізації цієї задачі: якщо підприємство зважилося на виконання поставленої задачі, йому знадобиться багато як грошових витрат, так і витрат часу; 
2) фахівці: керівництву слід усвідомлювати, що для постановки управлінського обліку йому слід наймати не бухгалтерів, а саме спеціалістів, у яких $\epsilon$ такий досвід. Однак варто розглянути ідею про залучення власних фахівців, а не тимчасових консультантів;

3) участь у процесі постановки: часто керівництво вважає, що не слід втручатися у ту сфеpy, де $\epsilon$ власні спеціалісти. Проте на це можна поглянути з іншого боку: як консультант чи фахівець будуть знати без активної участі керівництва про те, яку інформацію вони хотіли б бачити у себе на столі, щоб мати змогу приймати правильні управлінські рішення.

Висновки. Реорганізація системи управління виробничою діяльністю підприємства завдяки

\section{БІБЛІОГРАФІЯ}

1. Бєлоусова I. Роль управлінського обліку / I. Бєлоусова // Бухгалтерський облік і аудит. 2005. - № 4. - C. 34.

2. Гнилицька Л. Прийняття управлінських рішень на основі обліку інформації системи «директ-костинг» // Л. Гнилицька / Бухгалтерський облік і аудит. - 2007. - № 3. - С. 24.

3. Голов $C$. Ф. Проблеми та перспективи реформування бухгалтерського обліку в Україні / С. Ф. Голов // Бухгалтерський облік і аудит. 2000. - № 11. - C. 15-23.

4. Закон України «Про бухгалтерський облік і фінансову звітність в Україні» від 16.07.99 р. №996-ХІ (зі змінами і доповненнями) [Електронний ресурс]. впровадженню системи управлінського обліку відкриває принципово нові можливості для українських підприємств і дає змогу не тільки одержувати інформацію про виробничі процеси, але й оперативно використовувати іiі при прийнятті управлінських рішень.

Управлінський облік $\epsilon$ ефективним інструментом управління, тому що створює конкурентні переваги в ринковому середовищі, а саме, забезпечує підприємство ключовою інформацією. Досвід підприємств України свідчить, що практичне застосування управлінського обліку, на жаль, ще не набуло належного поширення, в зв'язку з невирішеним колом проблем. У сучасних умовах це питання вкрай актуальне й потребує свого дослідження.

- Режим доступу: http://www.ligazakon. ua.

5. Нападовська Л. В. Управлінський облік. [Підруч. для студентів вищих навч. закладів] / Нападовська Л. В. - К. : Книга, 2004. - 544 с.

6. Пушкар М. С. Розробка системи обліку : [Навчальний посібник] / Пушкар М. С. - Тернопіль : Карт-бланш, 2003. - 198 с.

7. Сук Л. К. Організація бухгалтерського обліку: [Підручник] / Сук Л. К., Сук П. Л. - К. : Каравела, 2009. - 624 с.

8. Чумаченко Н. Г. Розвиток управлінського обліку в Україні / Н. Г. Чумаченко // Світ бухгалтерського обліку. - 1999. - № 10-11. - С. 12. 